\title{
Local Wisdom-based Lesson in Designs for Batik Learning in Lesson Study Activity at Vocational Schools
}

\author{
I Kuntadi, I. Widiaty, L. Widaningsih, Ana \\ Faculty of Technology and Vocational Education \\ Universitas Pendidikan Indonesia \\ Bandung, Indonesia \\ iwakuntadi@yahoo.com
}

\begin{abstract}
The purpose of this study is to examine local wisdom-based lesson designs of batik learning in lesson study activity at vocational schools. Lesson designs examined are important signs that need to be considered in designing local wisdom-based batik learning. Research method used is Focus Group Discussion (FGD), with a panel team of expert consisting of Batik teachers at vocational schools, practitioners in batik industry, and researchers in the field of local wisdom-based learning and curriculum. The results showed that the main components in local-wisdom lesson designs developed consist of objectives, materials, methods, and evaluation and are summarized in the frame of cultural setting and wisdom values of the Indonesian nation. Local wisdom-based Batik Learning contains three main elements, namely artefacts, mentifacts, and sociofacts. Local wisdom-based learning implementation through lesson study activity is based on the similarities of the characteristics of these two things, which develop the aspects of reflective and critical thinking. Local wisdom-based Batik learning through lesson study activity is also expected to give a new atmosphere for teachers and learners at vocational schools.
\end{abstract}

Keywords- lesson design, lesson study, local wisdom, batik learning

\section{INTRODUCTION}

Local genius or local wisdom in the context of education found the right momentum with the implementation of character-based education in Indonesia. Exploration, assessment, and implementation of local wisdom values are capable of helping a country to achieve glory. Indonesia also knows local wisdom values in various aspects of life (SubakBali, Kampung Naga and Cireundeu, traditional culinary and art, and Batik).

Indonesian batik as a world cultural heritage has uniqueness in its symbols and philosophy. Batik contains priceless local wisdom values. These conditions suggest the need to constantly preserve batik, not merely as "batik working" but as a process of "batik education" [1].

One of the formal educational institutions that provide batik education or learning is textile and craft vocational school that has Skill Program of Batik. Batik subject is a subject filled with the local wisdom values. Batik itself is a representation of cultural and social life of Indonesian people. Batik has become a symbol of national culture that is unique and is not possessed by other nations [2].

Local wisdom-based learning is expected to be a part of character education. The talks of teaching wisdom have been a concern for future direction of learning. Teaching wisdom directs learners to be the citizens who possess character and responsibility [3] as well as helps learners to develop their knowledge wisely [4].

This study tried to examine local wisdom-based lesson plans for batik learning in the setting of lesson study activity. Lesson study, which originated in Japan, has been implemented in various countries including Indonesia. Batik learning at vocational schools is a learning filled with the aspects of local wisdom values. A significant similarity between lesson study and local wisdom-based batik learning at vocational schools is that both have the same principle, namely reflective and critical thinking.

\section{METHOD}

This study is a preliminary study to develop learning design in the form of local wisdom-based lesson design or lesson plan for batik learning at vocational schools. The method used is Focus Group Discussion (FGD). FGD activity or expert panel is intended to collect information on appropriate lesson design for batik learning in the setting of lesson study activity.

Experts who attended the FGD activity are 3 vocational teachers who teach batik subject, 2 practitioners in batik industry, and 5 researchers in batik learning.

Main points of the discussion examined in FGD activity are local wisdom values in batik learning at vocational schools, patterns/models of integration of local wisdom values in batik learning at vocational schools, local wisdom-based learning device in batik learning related to lesson plans, dimensions of local wisdom-based batik learning at vocational schools, and implementation of local wisdom-based batik learning at vocational schools through lesson study activity. 


\section{DISCUSSION}

\section{A. Characteristics of Learning of Lesson Study}

Lesson Study is a new breakthrough in the efforts to develop professionalism of teachers in improving learning process and outcomes. Lesson study is believed to be a systematic and integrated learning process that applies the principles of "research." Lesson Study suggests that learning process is documented in detail and is "disseminated" collaboratively and reflectively.

Literally, Lesson Study in Japanese is known as jugyokenkyu. Jugyo means lessons, kenkyu means study or research. Lesson study is not just the study of a subject, but a process of discovery and systematic evaluation (systematic inquiry) in teaching practice [5].

Lesson study in Japan is a process capable of changing the paradigm of learning and capable of helping Japan to reach the highest achievement in science and mathematics. The success of lesson study in Japan is influenced by several factors, these are: government's complete support of the policy (Sanctionedsupported), Lesson study is a very common activity in Japan (Prevalent), the implementation process of lesson study in Japan always involves advisors from outside the school (Enriched outside advisors), and lesson study in Japan is carried out openly (Enhanced by multiple means of disseminations) which is often called research learning presentation meeting [5].

Lesson study is a collaborative and reflective learning model, starting from planning (collaborative plan), implementation (collaborative learning) until evaluation (reflective learning), which are carried out in a collaborative atmosphere [5]. Lesson study is often called research lesson [6], observed lesson [7], and actual lesson [5]. Lesson study is a learning process that applies scientific principles like a study and is observed by many people in a direct learning.

Learning design developed in the context of the lesson study has unique characteristics which are always centered on learners' ways of thinking and activities. Lesson study model can improve the learning through increased teachers' insights from the aspect of content, pedagogy, and learners' ways of thinking [8]. The focus of learning using lesson study is on learners' ways of thinking [9].

Lesson study always directs learning on the learner's behavior and ways of thinking [10]. There are three aspects that must be considered in this context, namely learners' ways of thinking about the material studied, how learners solve learning problems and how teachers teach the content, and what is the best way to overcome these challenges. A skill called "research stance" or "research attitudes" and "researchable question" need to be developed, so that the goals of lesson study can be achieved well.

\section{B. Dimension of Local Wisdom-based Batik Learning}

Dimensions of local wisdom-based batik learning consist of the dimensions of objectives, materials, methods, and evaluation. These four dimensions of local wisdom-based batik learning become the basis for the development of lesson plans for batik learning that will be implemented in lesson study activity.

The dimensions of local wisdom-based batik learning can be seen in the table below: [1]

TABLE I. DIMENSION OF OBJECTIVES OF LOCAL WISDOM-BASED BATIK LEARNING

\begin{tabular}{cc}
\hline ASPECTS IN THE & LEARNING \\
DIMENSION OF & ACTIVITIES \\
OBJECTIVES & \\
\hline
\end{tabular}

Appreciation Teachers provide the
opportunities to see (watch) local wisdom on the motifs of batik and to observe carefully based on the available theories (niteni). Teachers can explain the history and background of batik creation, so that learners possess common understanding of the occurrence and position of batik in the culture system in Indonesia.

Technicality/Skill , Production begins with the process of exploration (nontoni and niteni); this process continues with the ability to express the observation results so that learners have appreciative understanding of the techniques and history of batik making. Production process is conducted with niroake or imitating and copying; in this case starting from the motifs, shapes, techniques, and technology as well as the principles of batik making. If it has been understood, then learners proceed to the step of modification (nambahi), that is, the process of the manipulation of shapes, techniques and objectives

Development Development of creative industry and application of local wisdom values on living the lives.

Source: Modification of [1]

Dimension of objectives on local wisdom-based batik learning directs learners to possess the appreciative ability to local wisdom valuse in the motifs of batik and in techniques of batik making, which are filled with the values of perseverance, 
thoroughness, and obedience to the rules of social system and local culture.

Dimensions of objectives also directs learners to be able to apply local wisdom values they have learned in everyday life. This talks illustrates that teaching wisdom is not merely learning the meaning of wisdom in school but also applying the meaning in everyday life [11].

TABLE II. DIMENSION OF MATERIALS OF LOCAL WISDOM-BASED BATIK LEARNING

\begin{tabular}{cc}
\hline ASPECTS IN & LEARNING ACTIVITIES \\
DIMENSION OF & \\
MATERIALS &
\end{tabular}

\begin{tabular}{ll}
\hline Facts & Every form or shape that can be \\
observed and arranged based on \\
the shape itself. The findings of \\
facts when the observation \\
process (nontoni) becomes \\
something new and serves as a \\
new thing in the context of batik \\
learning. \\
Facts in the form of ways or \\
steps in sequence. The \\
arrangement of these steps \\
cannot be done by their names, \\
therefore, they have to be in \\
sequence. \\
Characteristics of facts that have \\
been compiled into images and \\
are capable of generating \\
essentials. This is the essence of \\
batik learning.
\end{tabular}

SOURCE: MODIFICATION OF [1]

Dimension of materials in batik learning consists of three aspects: facts, procedures, and concepts/principles. Material content in batik learning will automatically refers to the facts of the Indonesian Nation cultural treasures. Materials of batik learning will describe the aspects of cultural diversity, nature, tradition, even the diversity of flora and fauna portrayed in every motif of batik. These facts are arranged in such a way in systematic learning procedures, so as to produce the concepts that describe the essences of batik learning, that is, wisdom.

TABLE III. Dimension of Methods of LocAL Wisdom-BASEd BAtiK LEARNING

\section{ASPECTS IN \\ DIMENSION OF METHODS}

Nontoni Doing the observation process, that is, the process of observing objects to understand the shape, content and background of batik making. This process is provided both in a systematic and non-systematic, ie through feeling, something will enter learners' memory.

$\begin{array}{ll}\text { Niteni } & \text { The selection process by sorting } \\ \text { knowledge and classifying it to new } \\ \text { knowledge (mind mapping). The process } \\ \text { will observe and classify the steps to create } \\ \text { and adjust the observation results into new } \\ \text { knowledge. The new knowledge in } \\ \text { learning batik is associated with } \\ \text { contemporary context. }\end{array}$

Niroake The process of mimicking and imitating the shape and pace and is preceded by schematization of the steps considered practical. Form imitation is initiated by copying the shapes and pace of making. This step will be automatically continued to nambahi. This process is related to the procedures or techniques in batik making.

Nambahi The process of addition, this means: modifying shapes. Modifying the existing shapes into another and modifying shapes for the benefit and development of the others. This process ends with the creation of products, either in the form of physical products, steps and new concepts of the findings of the shapes.

Dimension of methods of local wisdom-based batik learning contains systematic and distinctive steps (NontoniNiteni-Niroake-Nambahi). The methods applied in batik learning always begin with the observation of background of batik associated with the motifs of batik (artefacs aspect), the idea behind the making of batik (mentifacs aspects) and sociocultural setting at the time of batik production (sociofacts aspect). Although the process of batik making has its own rules but it does not deny the process of dynamization in creating new ideas and works, especially for contemporary batik.

The methods of batik learning which consists of four main steps illustrate important points that should exist in the context of local wisdom-based learning. Teaching for wisdom has a distinctive procedure, for example, learners need to observe and examine the socio-cultural setting behind the learning. Teaching for wisdom also suggests that local wisdom values learned need to be applied in everyday life [4]. 
TABLE IV. DIMENSION OF EVALUATION OF LOCAL-WISDOM BASED BATIK LEARNING

\begin{tabular}{|c|c|}
\hline $\begin{array}{c}\text { ASPECTS IN } \\
\text { DIMENTION } \\
\text { OF } \\
\text { EVALUATION }\end{array}$ & LEARNING ACTIVITIES \\
\hline Work Result & $\begin{array}{l}\text { Similar shapes } \\
\text { Similar ideas } \\
\text { Similar use } \\
\text { Similar principles and steps } \\
\text { Creativity }\end{array}$ \\
\hline Attitude & $\begin{array}{l}\text { Attitude in facing teachers. } \\
\text { Attitude in receiving learning } \\
\text { Attitude in completing assignments } \\
\text { Attitude in teamwork }\end{array}$ \\
\hline Knowledge & $\begin{array}{l}\text { Facts are assessed based on working } \\
\text { results } \\
\text { Procedures are assessed based on } \\
\text { working steps } \\
\text { Concepts are assessed based on } \\
\text { creative ability } \\
\text { Propositions or formulas are } \\
\text { assessed more comprehensively }\end{array}$ \\
\hline
\end{tabular}

SOURCE: MODIFICATION OF [1]

Dimension of evaluation in local wisdom-based batik learning illustrates the holistic aspects ranging from the aspect of knowledge, attitudes, and skills. These three aspects are interrelated to one another. An aspect that is interesting to consider in local wisdom-based learning is that evaluation is not only done on learners but also on teachers, who should act as "role models" [4]. Wisdom does not deny the aspect of knowledge and critical way of thinking, but it should be accompanied by the ethical aspects and the quality of partiality on the underlying social aspects [12].

\section{CONCLUSION}

Local wisdom-based batik learning is an integral part of character education. The purpose of local wisdom-based learning is to educate learners to become good citizens who care about themselves and their surroundings. Two main pillars which are the media of character education are the aspect of appreciation of batik motifs, which are filled with local wisdom values, and the process of batik production, which educates the soul with patience, persistence, thoroughness and care for the environment.

Dimensions of local wisdom-based batik learning consist of the aspects of objectives, materials, methods, and evaluation. These four dimensions are related to one another and direct learners to appreciate the cultural setting during the process of batik production. Local wisdom-based batik learning contains three main elements, namely artefact, mentifact, and sociofact.

Implementation of batik learning in lesson study activity shows significant similarities of these two things, namely both have the same principle, which is reflective and critical thinking. Lesson study can also be viewed as an approach in batik learning with a different atmosphere, which hones positive collaboration and improves teachers' professionalism.

\section{REFERENCES}

[1] Wagiran. (2011). Pengembangan Model Pendidikan Kearifan Lokal Dalam Mendukung Visi Pembangunan Provinsi Daerah Istimewa Yogyakarta 2020 (Tahun Kedua). Jurnal Penelitian Dan Pengembangan $\mathrm{N}, 3(5), 1-29$

[2] Ismail, T., Wiyantoro, L. S., \& Muchlish, M. (2012). Strategy, Interactive Control System and National Culture: A Case Study of Batik Industry in Indonesia. Procedia - Social and Behavioral Sciences, 65(ICIBSoS), 33-38. http://doi.org/10.1016/j.sbspro.2012.11.087

[3] Halpern, D.F., (2010). Why Wisdom?. Educational Psychologist, 36(4), 253-256. http://doi.org/10.1207/S15326985EP3604

[4] Sternberg, R. J. (2001). Why Schools Should Teach for Wisdom: The Balance Theory of Wisdom in Educational Settings. Educational Psychologist, 36(4), 227-245. http://doi.org/10.1207/S15326985EP3604_2

[5] Fernandez, C., Cannon, J., \& Chokshi, S. (2003). A US-Japan lesson study collaboration reveals critical lenses for examining practice. Teaching and Teacher Education, 19(2), 171-185. http://doi.org/10.1016/S0742-051X(02)001026

[6] Cerbin, W., \& Kopp, B.(2009). Lesson Study as a Model for Building Pedagogical Knowledge and Improving Teaching. International Journal of Teaching and Learning in Higher Education, 18(3), 250-257.

[7] Lewis, C., Perry, R., \& Murata, a. (2006). How Should Research Contribute to Instructional Improvement? The Case of Lesson Study. Educational Researcher, 35(3), 3-14. http://doi.org/10.3102/0013189X035003003

[8] Lewis, C. C., Perry, R. R., \& Hurd, J. (2009). Improving mathematics instruction through lesson study: A theoretical model and North American case. Journal of Mathematics Teacher Education, 12(4), 285304. http://doi.org/10.1007/s10857-009-9102-7

[9] Perry, R. R., \& Lewis, C. C. (2009). What is successful adaptation of lesson study in the US? Journal of Educational Change, 10(4), 365-391. http://doi.org/10.1007/s10833-008-9069-7

[10] Fernandez, C. (2005). Lesson Study: A Means for Elementary Teachers to Develop the Knowledge of Mathematics Needed for Reform-Minded Teaching? Mathematical Thinking and Learning, 7(4), 265-289. http://doi.org/10.1207/s15327833mt10704_1

[11] Yang, S. Y. (2013). Wisdom and good lives: A process perspective. New Ideas in Psychology, 31(3), 194-201. http://doi.org/10.1016/j.newideapsych.2013.03.001

[12] Reznitskaya, A., \& Sternberg, R. J. (2004). Teaching Students to Make Wise Judgments: The "Teaching for Wisdom" Program. Chapter 11. Teaching and Learning: Methods and Process. 